\title{
RANCANG BANGUN TURBIN ANGIN TIPE DARRIEUS TIGA SUDU RANGKAP TIGA DENGAN PROFIL NACA 0006
}

\author{
Anis Fadila ${ }^{(1)}$, Ilham Zakaria ${ }^{(2)}$, Muhammad Fauzan ${ }^{(3)}$, Sahid $^{(4)}$, Supriyo ${ }^{5)}$ \\ Jurusan Teknik Mesin Politeknik Negeri Semarang \\ Jl. Prof H. Sudarto, SH., Tembalang, Kotak Pos 6199/SMS, Semarang 50329 Telp. 7473417, 7499585
}

(Hunting), Fax.7472396

\begin{abstract}
Abstrak
Turbin angin Darrieus merupakan turbin angin sumbu vertical yang memilki poros rotor utama disusun tegak lurus dengan kelebihan utama dapat mengkonversi energi angin dari segala arah.Tujuan penelitian ini yaitu Membuat, melakukan uji kinerja dan analisis kinerja model turbin angin Darrieus tiga sudu rangkap tiga profil NACA 0006dan tiga sudu tunggal profil NACA 0018.Metode peneitian meliputi perancangan desain turbin angin Darrieus tiga sudu rangkap tiga, pembuatan, perakitan turbin angin, proses pengujian, dan metode analisis data. Pengujian dilakukan pada kecepatan angin 7-12 $m /$ detik.Analisis uji kinerja turbin angin didasarkan pada perhitungan efisiensi sistem $\left(\eta_{\text {sistem }}\right)$. Hasil uji menunjukkan efisiensi sistem tertinggi tiga sudu rangkap tiga NACA 0006 memiliki efisiensi terbesar pada kecepatan angin 7 sampai $11 \mathrm{~m} /$ detik yaitu 0,0977 dibandingkan dengan tiga sudu tunggal NACA 0018 yang memiliki efisiensi terbesar hanya pada kecepatan angin $12 \mathrm{~m} /$ detik yaitu sebesar 0,154.
\end{abstract}

Kata kunci : "Turbin angin Darrieus", "NACA 0018", "NACA 0006", "efisiensi sistem", "tip speed ratio"

\section{Pendahuluan}

Indonesia terkenal sebagai negara yang kaya dengan potensi sumber daya alamnya terutama energi.Berdasarkan jenisnya energi dapat digolongkan menjadi dua, yaitu energi terbarukan (renewable energy) dan energi tidak terbarukan (nonrenewable energy).Sumber energi yang dapat diperbarui misalnya energi angin, biomassa, biogas, energi kayu. Sedangkan sumber energi seperti minyak bumi, batubara, gas alam adalah sumber energi yang bersifat tidak dapat diperbarui atau dapathabis.

Kebutuhan energi di Indonesia terus mengalami peningkatan, hal ini disebabkan dengan adanya pertambahan penduduk, pertumbuhan ekonomi,dan pola konsumsi energi itu sendiri yang senantiasa meningkat.Sumber energi tidak dapat diperbarui (non-renewable energy) seperti energi fosil khusunya bahan bakar minyak yang selama ini menjadi sumber energi utama, ketersediaannya sangat terbatas dan terus mengalami penipisan. Gas alam diprediksi para ahli akan habis lebih kurang 100 tahun lagi, sedangakan cadangan batubara akan habis lebih kurang 200-300 tahun yang akan datang. Untuk terus menyediakan energi fosil memerlukan proses alam yang membutuhkan waktu yang sangat lama. Kondisi ini sangat mengkhawatirkan terutama bagi kelangsungan hidup manusia.Upaya-upaya

pencariansumberenergi alternatif selain fosil terus dilakukan untuk mencari energi terbarukan.

Salah satu energi terbarukan yang berkembang pesat didunia saat ini adalah energi angin. "Angin merupakan sumber energi yang terbarukan. Pemanfaatan angin sebagai sumber energi sudah lama dilakukan oleh manusia" (Hofman dan Harun, 1987). Energi angin merupakan energi terbarukan yang sangat fleksibel. Energi angin dapat dimanfaatkan untuk berbagai keperluan misalnya pembangkit listrik, pemompaan air untuk irigasi, pengeringan atau pencacah hasil panen, aerasi tambak ikan/udang, dan lain sebagainya. Selain itu pemanfaatan energi angin dapat dilakukan baik di daerah landai maupun dataran tinggi, bahkan dapat diterapkan dilaut, berbeda halnya dengan energi air. Angin merupakan salah satu sumber energi potensial yang kuantitasnya cukup banyak untuk daerah - daerah di Indonesia, tetapi belum banyak di manfaatkan. Padahal Indonesia 
merupakan wilayah potensial untuk pengembangan pembangkit listrik tenaga angin karena termasuk negara kepulauan dengan $2 / 3$ wilayahnya merupakan lautan dan mempunyai garis pantai yang sangatpanjang.Pembagi kelas angin dapat dilihat pada tabel 1.1.

Tabel 1.1 Kondisi Angin

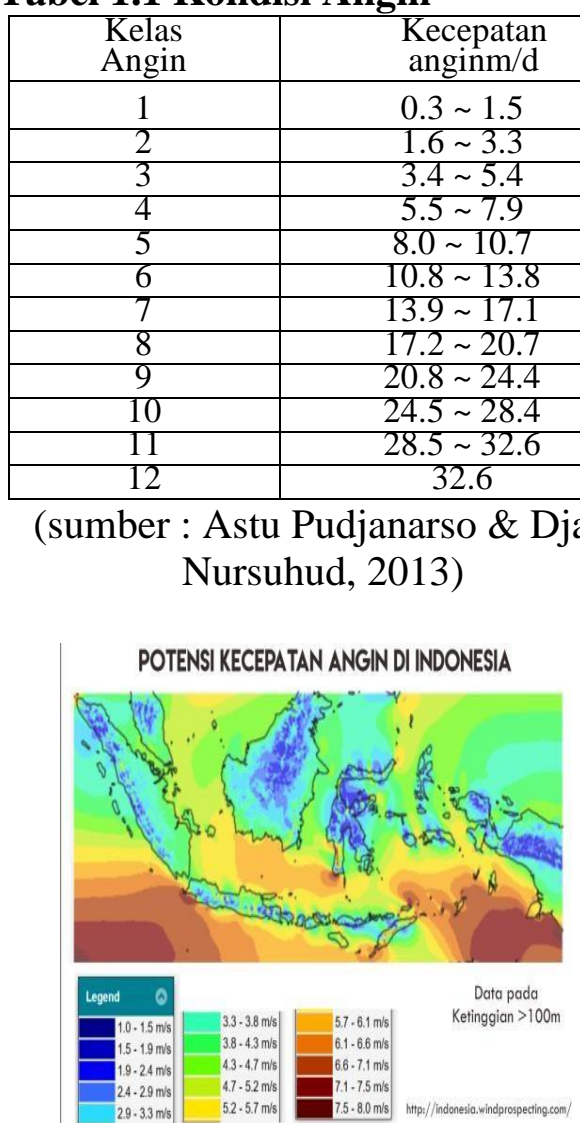

Gambar 1.1 Potensi Kecepatan Angin Di

Indonesia

(sumber :

http://indonesia.windprospecting.com/)

Pada peta di atas (gambar 1.1) ditunjukkan daerah daerah di Indonesia yang memiliki potensi energi angin berdasarkan data kecepatan angin rata-rata. Berdasarkan kriteria turbin angin seperti turbin angin Darrieus, maka dibutuhkan anginberkecepatan minimal $6 \mathrm{~m} /$ detik. Daerah yang memiliki kecepatan rata-rata angin di atas $6 \mathrm{~m} /$ detik banyak ditemui pada pulau-pulau di Indonesia bagian timur. Berdasarkan data potensi angin tersebut dilakukan pengembangan turbin angin Darrieus skala laboratorium (modeling) dengan variasi National
Advisory Committe for Aeronautics

(NACA).

\section{TINJAUANPUSTAKA \\ 2.1 TurbinAngin}

Turbin angin adalah alat yang digunakan untuk membangkitkan tenaga listrik menggunakan media angin. Keeeppassip dasar kerjkecdparantandim angin angin $\mathrm{km} / \mathrm{jam}$ mengubah en $\mathrm{knot} / \mathrm{jam}$ mekanis dari

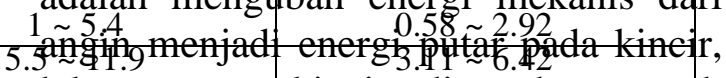
12.14tul9.putaran kincir 6. diguhiskan untuk

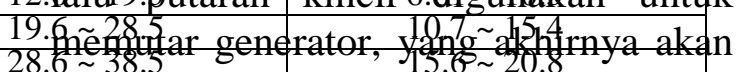
38.menghasilkan listrik.Bierduss.8rkan letak 49.8un 61 b.

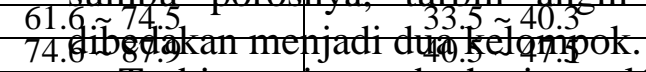
88.0 +. IIOarbin angin sumbar.herssontal(TASH) 102.42. Tht bin angin sumb5.4er6ikal(TASV). Gambar 2.1 berikut ${ }^{63.4}$ menunjukkan jenis-jenis turbin yang digolongkan berdasarkan letak sumbu porosnya.

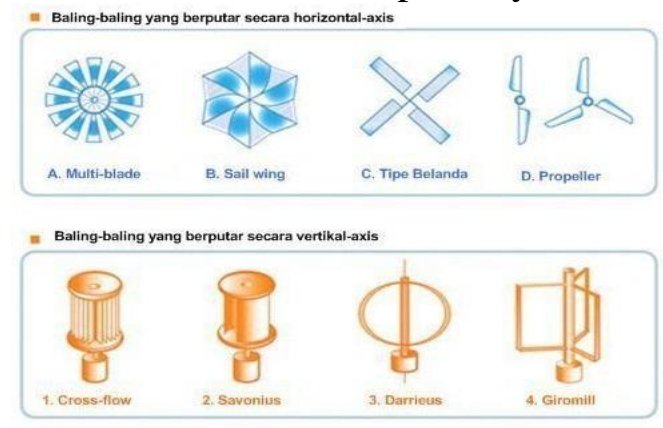

Gambar 2.1 Jenis - jenis Turbin Angin

\subsection{TurbinDarrieus}

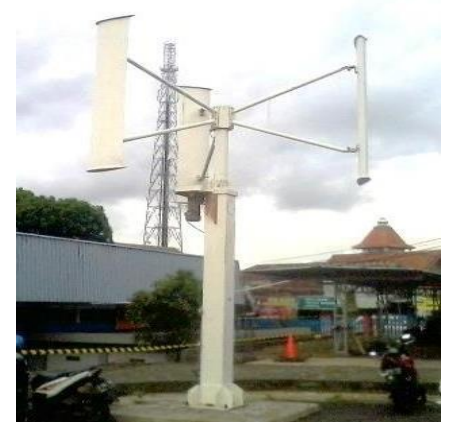

Gambar 2.2 merupakan gambar turbin angin tipe Darrieus yang terdapat pada kampus Politeknik Negeri Semarang.

Gambar 2.2 Turbin Darrieus(sumber : Dokumentasi Pribadi). "Turbin angin sumbu vertikal tipe Darrieus dipatenkan oleh G.J.M. Darrieus di Amerika Serikat 
pada tahun 1931" (Abdul Kadir, 2005). Turbin tersebut diciptakan kembali oleh insinyur di Dewan Pengembangan National Kanada pada awaltahun 1970. Laboratorium Sandia membangun Darrieus dengan diameter $5 \mathrm{~m}$ pada tahun 1974 dan sejak itu pengembangan turbin angin tipe Darrieus terus dilakukan. Kebanyakan turbin angin yang didesain untuk memproduksi listrik memiliki 2 atau tiga sudu yang berputar secara horizontal. Sudu yang dibuat ini cenderung mahal dan termasuk alat berteknologi tinggi. Masalah inilah yang membuat para peneliti mencari solusi untuk alat yang lebih simple dan murah.

Prinsip kerjanya berdasarkan pada fakta bahwa kecepatan sudu adalah kelipatan dari kecepatan angin, sehingga besarnya angin yang dapat ditangkap oleh sudu turbin tergantung pada variasi sudut sudu. Bila dilihat dari perspektif sudu, gerakan rotasi dari sudu yang diakibatkan oleh angin merupakan hasil dari daya kinetik angin yang menabrak sudu dengan daya mekanik yang dimiliki turbin. Jika sudut serang dari angin pada sudu lebih besar dari nol, maka akan timbul gaya angkat yang dapat mendorong sudu turbin untuk bergerak. Sudut serang yang bervariasi antara -20 sampai +20 derajat, tidak boleh melebihi 20 derajat karena pada sudut lebih tinggi aliran sepanjang sudu tidak laminar lagi, yang merupakan kondisi yang diperlukan untuk menimbulkan dari gaya angkat, tapi menjadi turbulen yang menyebabkan putaran sudu terhambat. Sudut serangan antara nol dan 20 derajat dapat menghasilkan putaran yang tinggi pada sudu. "Turbin Darrieus dapat menangkap angin dari segala penjuru, turbin ini tidak memerlukan sudu pengatur arah angin. Dikemudian hari turbin Darrieus mungkin dapat mengatur dirinya sendiri dengan sudu-sudu yang dapat bergerak turun naik sepanjang poros, mengubah bentuknya sesuai dengan kecepatan angin" (Mike Cross, 1987).

Turbin Darrieus memiliki beberapa kekurangan seperti getaran yang kekerasan sehingga dapat menyebabkan kerusakan sudu, dan tingkat kebisingan yang tinggi dan efisiensi yang relatif rendah. Dari gambar dapat dilihat prinsip kerja dari turbin Darrieus bahwa resultan dari kecepatan angin dan kecepatan udara karena rotasi membentuk sudut positif dari sudut serang gaya angkat padasudu.Prinsip kerja turbin angin tipe Darrieusdapat dilihat pada gambar 2.3.

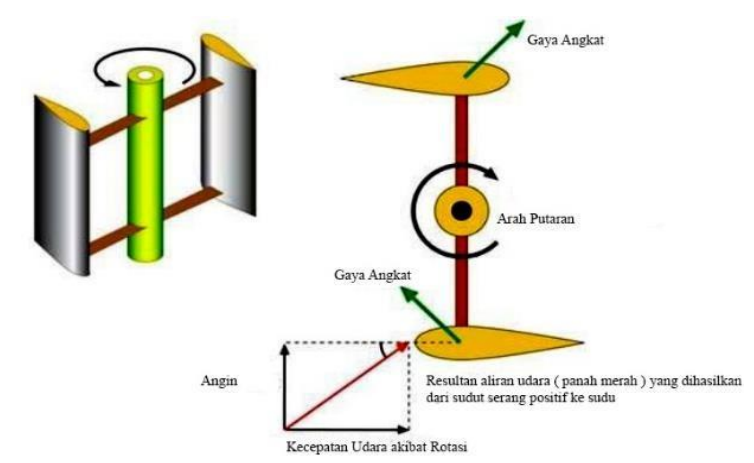

Gambar 2.3 Prinsip kerja turbin Darrieus

Turbin angin Darrieus memiliki torsi rotor yang relatif rendah tetapi putarannya lebih tinggi dibanding dengan turbin angin Savonius sehingga lebih diutamakan untuk menghasilkan energi listrik. Namun turbin ini membutuhkan energi awal yang lebih besar untuk mulaiberputar.

Turbin angin Darrieus biasanya akan mulai berputar pada kecepatan angin 2,5 $\mathrm{m} /$ detik dan dapat menghasilkan daya pada kecepatan angin $3 \mathrm{~m} /$ detik. Turbin angin Darrieus memiliki sududengan penampang berbentuk airfoil. Efisiensi maksimum turbin angin tipe Darrieus-H untuk saat ini masih berada pada $42 \%$, sedangkan turbin angin tipe horizontal mempunyai efisiensi maksimum sebesar $50 \%$. Hal ini mengakibatkan turbin angin tipe Darrieus jarang dipakai untuk pembangkit listrik dengan kapasitas yangbesar.

\subsection{AirfoilNACA}

NACA Airfoil adalah bentuk airfoil 
sayap pesawat udara yang dikembangkan oleh National Advisory Committee for Aeronautics (NACA). Sampai sekitar perang dunia ke II, Airfoil banyak digunakan adalah hasil riset Gottingen. Selama periode ini banyak pengujian airfoil dilakukan berbagai negara, namun hasil riset $N A C A$ adalah yang paling terkemuka. Pengujian yang dilakukan NACA lebih sistematik dengan membagi pengaruh efek kelengkungan dan distribusi ketebalan serta pengujiannya dilakukan pada bilangan Renault yang lebih tinggi dibandingkan dengan yang lain. Berikut ini adalah identifikasi angka seri dari $N A C A$ "empat angka" tersebut:

1. Angka pertama adalah maksimum camber dalam perseratuschord.

2. Angka kedua adalah Posisi maksimum camber pada chord line dalam sepersepuluh chord dari leading edge.

3. Dua angkaterakhir dalammaksimum ketebalan dalam seperseratuschord Misalnya untuk airfoil dengan NACA 0006 (seri empat angka) memiliki camber maksimum 0c terletak di 0c dari leading edge, dan maksimum ketebalan 0.06c. Dalam pratek, umumnya angka- angka ini dinyatakan dalam persen tali busur, yaitu: camber $0 \%$ di 0\%cdengan tebal $6 \%$. Untukairfoil NACA 0006 dapat dilihat pada gambar 2.4.

Gambar 2.4 NACA 0006(sumber:

http://airfoiltools.com/airfoil/details?airfoil=n aca0006-il)

\subsection{Teori momentum ElementerBetz}

Teori momentum elementer Betz sederhana berdasarkan pemodelan aliran dua dimensi angin yang mengenai rotor menjelaskan prinsip konversi energi angin pada turbin angin. Kecepatan aliran udara berkurang dan garis aliran membelok ketika melalui rotor dipandang pada satu bidang. Berkurangnya kecepatan aliranudaradisebabkan sebagian energi kinetik angin diserap oleh rotor turbin angin. Pada kenyataannya, putaran rotor menghasilkan perubahan kecepatan angin pada arah tangensial yang akibatnya mengurangi jumlah total energi yang dapat diambil dari angin. Walaupun teori elementer Betz telah mengalami penyederhanaan, namun teori ini cukup baik untuk menjelaskan bagaimana energi angin dapat dikonversi menjadi bentuk energi lainnya. Dengan menganggap bahwa kecepatan udara yang melalui penampang $\mathrm{A}$ adalah sebesar $\mathrm{v}$, maka aliran volume udara yang melalui penampang rotor pada setiap satuan waktu adalah

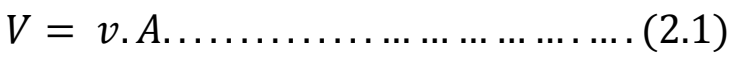

dimana :

$\mathrm{V}=$ laju volume udara $\left(\mathrm{m}^{3} / \mathrm{s}\right)$

$\mathrm{v}=$ kecepatan angin $(\mathrm{m} /$ detik)

$\mathrm{A}=$ luas area sapuan rotor $(\mathrm{m} 2)$

Dengan demikian, laju aliran massa dapat dirumuskan dengan persamaan

$$
\dot{\mathrm{m}}=\rho \cdot V \cdot A
$$

dimana :

$\rho=$ massa jenis udara $(\mathrm{kg} / \mathrm{m} 3)$

Persamaan yang menyatakan energi kinetik yang melalui penampang A pada setiap satuan waktu dapat dinyatakan sebagai daya yang melalui penampang A adalah:

$$
\mathrm{P}=\frac{1}{2} \rho \cdot v^{3} \cdot A
$$

dimana :

$\mathrm{P}=$ daya kinetik (Watt)

Energi kinetik dapat diambil dari angin dengan mengurangi kecepatannya. Artinya kecepatan udara di belakang rotor akan lebih rendah daripada kecepatan udara di depan rotor. Gambar 2.2 menunjukkan kondisi aliran udara akibat ekstraksi energi mekanik aliran bebas dimana kecepatan angin setelah mengalami ekstraksi $\left(\mathrm{V}_{2}\right)$ lebih rendah 
daripada kecepatan angin sebelum mengalami ekstraksi $\left(\mathrm{V}_{1}\right)$. Energi mekanik yang diambil dari angin setiap satuan waktu didasarkan pada perubahan kecepatannya dapat dinyatakan dengan persamaan:

$$
\begin{aligned}
& P=\frac{1}{2} \cdot \rho \cdot v_{1}^{3} \cdot A_{1}-\frac{1}{2} \cdot \rho \cdot v_{2}^{3} \cdot A_{2} \\
& =\frac{1}{2} \cdot \rho\left(v_{1}^{3} \cdot A_{1}\right. \\
& \left.-v_{2}^{3} \cdot A_{2}\right) \ldots \ldots \ldots \ldots \ldots \cdot(2.4)
\end{aligned}
$$

dimana:

$\mathrm{P}=$ daya yang diekstraksi (Watt)

$\rho=$ massa jenis udara $\left(\mathrm{kg} / \mathrm{m}^{2}\right)$

A1 = luas penampang aliran udara sebelum melalui rotor $\left(\mathrm{m}^{2}\right)$

A2 = luas penampang aliran udara setelah melalui rotor $\left(\mathrm{m}^{2}\right)$

$\mathrm{v} 1=$ kecepatan aliran udara sebelum melewati rotor ( $\mathrm{m} /$ detik)

$\mathrm{v} 2=$ kecepatan aliran udara setelah melewati rotor $(\mathrm{m} /$ detik)

Dengan asumsi massa jenis tidak mengalami perubahan maka sesuai hukum kontinuitas sebagai berikut :

$$
\rho \cdot v_{1} \cdot A_{1}=\rho \cdot v_{2} \cdot A_{2}
$$

Kondisi aliran udara akibat ekstraksi energi mekanik aliran bebas dapat dilihat pada Gambar 2.2.

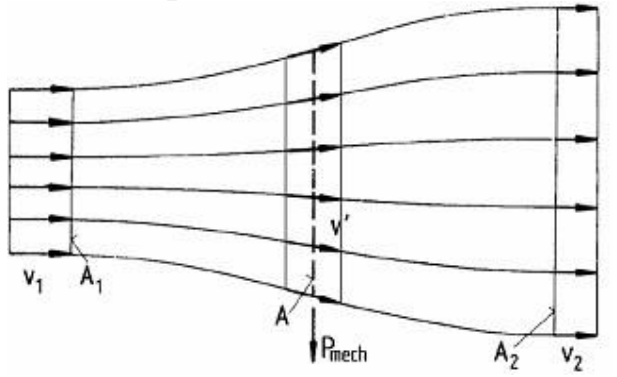

Gambar 2.5 Kondisi Aliran Udara Akibat Ekstraksi Energi Mekanik Aliran Bebas (sumber: Erich Hau, 2005)

Dari persamaan tersebut dapat disimpulkan bahwa daya terbesar yang diambil dari angin adalah jika $\mathrm{v}_{2}$ bernilai nol, yaitu angin berhenti setelah melalui rotor. Namun hal ini tidak dapat terjadi karena tidak memenuhi hukum kontinuitas.
Energi angin yang diubah akan semakin besar jika $\mathrm{v}_{2}$ semakin kecil, atau dengan kata lain rasio $\mathrm{v}_{1} / \mathrm{v}_{2}$ harus semakin besar.

Persamaan lainnya yang diperlukan untuk mencari besarnya daya yang dapat diambil adalah persamaan momentum

$$
F=\dot{\mathrm{m}}\left(v_{1}-v_{2}\right)
$$

dimana:

$\mathrm{F}=\operatorname{gaya}(\mathrm{N})$

$\dot{\mathrm{m}}=$ laju aliran massa udara $(\mathrm{kg} / \mathrm{s})$

Sesuai dengan hukun ke-2 Newton bahwa gaya aksi akan sama dengan gaya reaksi, gaya yang diberikan udara kepada rotor akan sama dengan gaya hambat oleh rotor yang menekan udara ke arah yang berlawanan dengan arah gerak udara. Daya yang diperlukan untuk menghambat aliran udara adalah:

$P=F \cdot v^{\prime}=\dot{\mathrm{m}}\left(v_{1}-v_{2}\right) v^{\prime}$

dimana :

$\mathrm{v}^{\prime}=$ kecepatan aliran udara pada rotor (m/detik)

Kedua persamaan diatas menunjukkan hubungan

$$
\begin{aligned}
& \frac{1}{2} \dot{\mathrm{m}}\left(v_{1}-v_{2}\right)=\dot{\mathrm{m}}\left(v_{1}-v_{2}\right) v^{\prime} \ldots \ldots . \\
& \quad \begin{array}{l}
\text { Sehingga, } \\
v^{\prime}=\frac{1}{2}\left(v_{1}+v_{2}\right) \ldots \ldots \ldots \ldots \ldots \ldots \ldots \ldots \ldots \ldots \ldots
\end{array}
\end{aligned}
$$

Maka kecepatan aliran udara ketika melalui rotor adalah

$$
v^{\prime}=\frac{v_{1}+v_{2}}{2}
$$

Laju aliran massa menjadi

$$
\dot{\mathrm{m}}=\rho \cdot A \cdot v^{\prime}=\frac{1}{2} \rho \cdot A\left(v_{1}+v_{2}\right)(2
$$

Sehingga daya mekanik output dapat ditulis

$$
P=\frac{1}{2} \rho \cdot A\left(v_{1}^{2}-v_{2}^{2}\right)\left(v_{1}+v_{2}\right)(2
$$


Supaya dapat dijadikan referensi untuk daya output tersebut, maka dapat dibandingkan dengan daya aliran bebas yang mengalir dengan luas sapuan yang sama tanpa ada ekstraksi. Dirumuskan sebagai berikut.

$$
P_{0}=\frac{1}{2} \rho \cdot v_{1}^{3} \cdot A
$$

\subsection{TSR (Tip Speed Ratio)}

Tip Speed Ratio (Rasio kecepatan ujung) adalah rasio kecepatan ujung rotor terhadap kecepatan angin bebas. Untuk kecepatan angin nominal yang tertentu, tip speed ratio akan berpengaruh pada kecepetan putar rotor.

$$
\lambda=\frac{\mathrm{u}}{\mathrm{v}}=\frac{(\pi \cdot D \cdot n) / 60}{\mathrm{v}}
$$

\subsection{Efisiensi sistem}

Perbandingan antara daya keluaran rotor terhadap daya input yang melalui penampang rotor disebut efisiensi sistem ( $\eta$ sistem). Dirumuskan dengan :

$$
\eta_{\text {sistem }}=\frac{\text { Poutput }}{\text { Pinput }}=\frac{\text { Pgenerator }}{\text { Pangin }}
$$

\subsection{Generator AC}

Generator Arus Bolak-balik sering disebut juga sebagai alternator atau generator AC (alternating current). Generator arus bolak-balik dibagi menjadi dua jenis, yaitu:

a. Generator arus bolak-balik 1 fasa.

b. Generator arus bolak-balik 3 fasa.

\subsection{Prinsip Kerja Generator}

Prinsip dasar generator arus bolakbalik menggunakan hukum Faraday yang menyatakan jika sebatang penghantar berada pada medan magnet yang berubahubah, maka pada penghantar tersebut akan terbentuk gaya gerak listrik. Besar tegangan generator bergantung pada :

1. Kecepatan putaran $(\mathrm{N})$.

2. Jumlah kawat pada kumparan yang memotong fluk $(\mathrm{Z})$.

3. Banyaknya fluk magnet yang dibangkitkan oleh medan magnet $(\varnothing)$.

Gambar 2.5 merupakan gambar prinsip kerja generator.

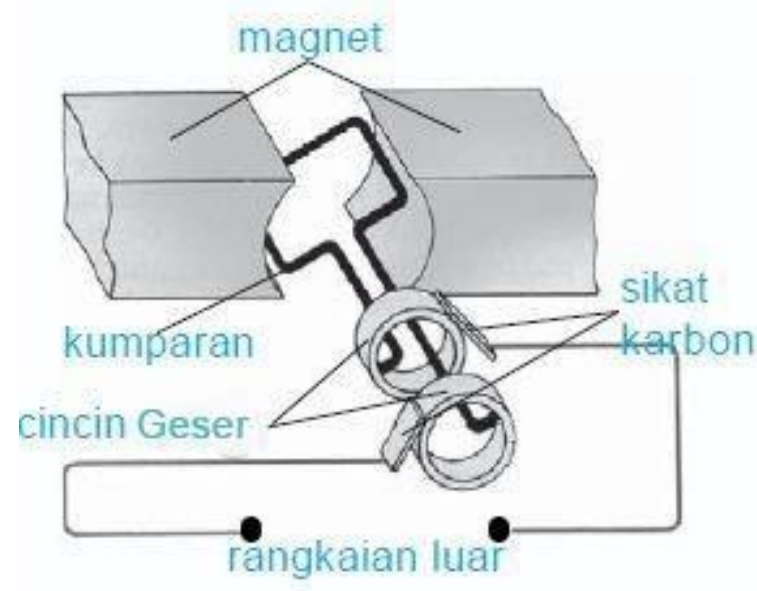

Gambar 2.6 Prinsip Kerja Generator (sumber: http://www.duniapendidikan.net/)

Jika kumparan kawat dihubungkan dengan rangkaian listrik tertutup, maka akan timbul pula arus listrik yang mengalir pada rangkaian

$$
\begin{aligned}
& E=c . n . \emptyset \\
& E=B . l \cdot v \sin \\
& \text { dimana: } \\
& \mathrm{c}=\text { konstanta } \\
& \mathrm{n}=\text { kecepatan }(\mathrm{rad} / \mathrm{s}) \\
& \emptyset=\text { fluks (Weber) } \\
& E=\text { ggl induksi (Volt) } \\
& \mathrm{B}=\text { induksi magnet }(\mathrm{T}) \\
& 1=\text { panjang kawat }(\mathrm{m}) \\
& v=\text { kecepatan potong medan }(\mathrm{rad} / \mathrm{s})
\end{aligned}
$$

\section{METODOLOGI PELAKSANAAN}

Alur metode pelaksanaan dapat dilihat pada gambar 3.1. 


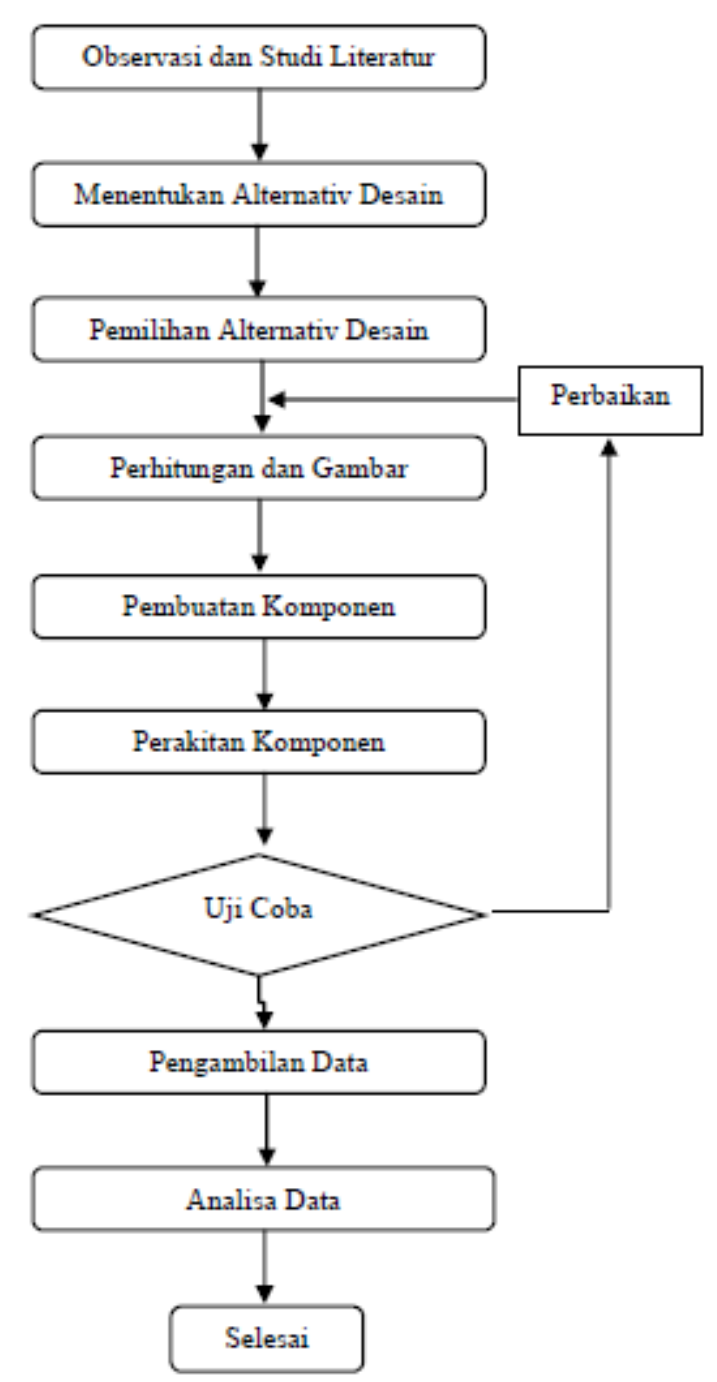

Gambar 3.1 Flow Chart Metode Pelaksanaan

\subsection{Perancangan dan Pembuatan}

Proses perancangan desain turbin angin Darrieus tiga sudu rangkap tiga NACA 0006 menggunakan software gambar teknik SolidWork. Desain dari tiap bagiannya adalah seperti berikut:

1. Desain Rangka Utama

Rangka dibuat sekokoh mungkin yaitu dari besi bahan besi profil L ukuran $4 \mathrm{~cm} \times 4 \mathrm{~cm}$ $\mathrm{x} 4 \mathrm{~cm}$ dilas dan dibentuk menyerupai bentuk limas.

2. Desain Flange Sudu

Flange sudu menggunakan material besi ST37 tebal $10 \mathrm{~mm}$. Jarak antara pusat flange dengan slot dudukan sudu adalah $250 \mathrm{~mm}$ atau sama dengan $1 / 2$ dari diameter putaran turbin.

3. Desain Sudu
Desain sudu berbasis NACA 0006 berdimensi tebal $6,6 \mathrm{~mm}$, panjang line chord $11 \mathrm{~cm}$ dan panjang sudu $70 \mathrm{~cm}$, dan dibuat beradius sesuai dengan radius sapuan turbin masing-masing R250; R236,8; dan R223,6. Material sudu dibuat menggunakan plat alumunium tebal 0,30 $\mathrm{mm}$.

\section{Poros}

Poros turbin mengunakan besi ST 37 berdiameter $1,8 \mathrm{~cm}$.

\section{Pulley}

Ukuran pulley pada poros yaitu diameter $12 \mathrm{~cm}$ dan pulley pada poros generator 6 $\mathrm{cm}$

\section{Belt}

Menggunakan timing belt diameter $23 \mathrm{~cm}$ menyesuaikan jarak antara pulley poros utama dengan pulley poros generator. Luaran produk yang telah dihasilkan dari proses rancang bangun sudu turbin Darrieus dari bahan plat alumunium dapat dilihat pada gambar 3.1.

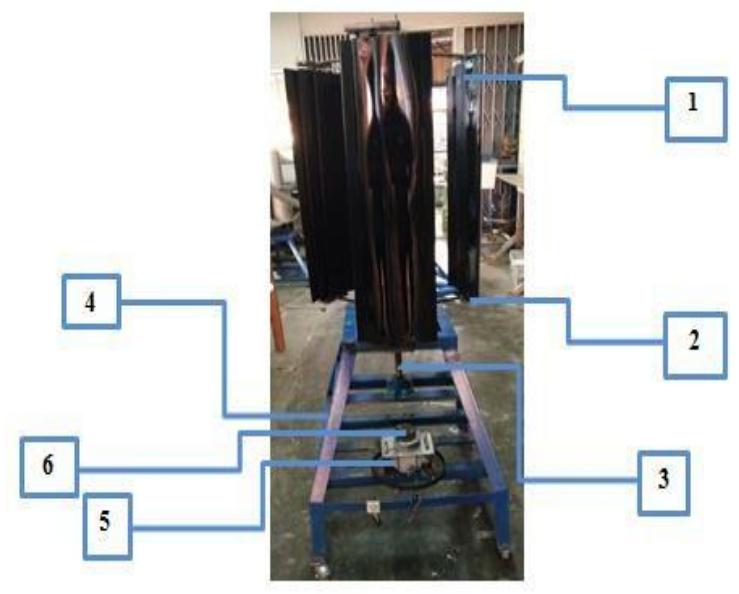

Gambar 3.2 Turbin Angin Darrieus dengan profil NACA 0006. (1) Sudu turbin NACA 0006; (2) Pemegang sudu; (3) Poros turbin; (4) Rangka turbin; (5) Generator; (6) Puli.

\subsection{Prosedur Pengujian}

1. Langkah-langkah yang dilakukan dalam pengujian turbin angin adalah :

2. Menyiapkan peralatan yang akan digunakan dalam pengujian seperti yang telah disebutkan pada langkah di atas.

3. Memeriksa dan memastikan keadaan peralatan tersebut sebelum digunakan. 
4. Menempelkan stiker berwarna alumunium/skotlite pada poros turbin untuk mendapatkan putaran sudu.

5. Memasang sudu turbin yang akan diuji, yaitu sudu tunggal dan sudu ganda.

6. Mengencangkan baut-baut yang berada dibawah dan diatas sudu turbin.

7. Mengatur jarak antara turbin angin dengan blower dan disesuaikan dengan kecepatan angin terendah yaitu 7 $\mathrm{m} /$ detik hingga kecepatan maksimal 12 $\mathrm{m} /$ detik. Memberi tanda pada tanah untuk kecepatan $7 \mathrm{~m} /$ detik hingga 12 $\mathrm{m} /$ detik.

8. Memindahkan turbin angin Darrieus sejenak untuk mengukur kecepatan angin.

9. Menyalakan blower, kemudian mengukur kecepatan angin dengan menggunakan anemometer yang diposisikan antara jarak blower dengan tanda pada tanah yang telah dibuat. Mencatat kecepatan angin yang terukur pada anemometer pada tabel. Jika telah selesai matikan blower.

10. Setting turbin angin pada tanda jarak di tanah untuk kecepatan terendah terlebih dahulu ( $7 \mathrm{~m} /$ detik) dilanjutkan kecepatan yang lebih tinggi.

11. Menyalakan blower dan menunggu beberapa saat sudu turbin angin berputar hingga putaran sudu stabil. Membaca kecepatan putaran rotor menggunakan tachometer. Membaca arus dan tegangan yang terbaca pada amperemeter dan voltmeter. Pada tahap ini dilakukan tanpa beban.

12. Memberikan beban pada turbin angin dari tiap rangkaian seri tahanan geser. Mencatat arus, tegangan, dan kecepatan putaran rotor pada tabel.

13. Melakukan pembebanan pada turbin angin hingga turbin angin tidak dapat lagi berputar.

14. Jika pengujian sudah selesai, mengulangi langkah nomor 4 hingga nomor 12 dengan mengganti jenis sudu lainnya.
15. Selesai melaksanakan pengujian, merapikan semua peralatan dan mengembalikan pada kondisi semula.

\subsection{Metode Analisa Data}

1. Memasukkan data pengujian ke dalam tabel 3.1 data pengujian dengan format sebagai berikut :

Tabel 3.1 Tabel Pengujian

\begin{tabular}{|c|c|c|c|c|c|c|}
\hline No. & $\begin{array}{c}\mathrm{V}_{\text {angin }} \\
(\mathrm{m} / \text { detik })\end{array}$ & $\begin{array}{c}\mathrm{V}_{\text {angin }} \\
\text { depan sudu } \\
(\mathrm{m} / \text { detik })\end{array}$ & $\begin{array}{c}\text { Beban } \\
\text { (Watt) }\end{array}$ & $\begin{array}{c}\mathrm{n} \\
(\mathrm{Rpm})\end{array}$ & $\begin{array}{c}\mathrm{V} \\
(\text { Volt })\end{array}$ & $\begin{array}{c}\mathrm{I} \\
\text { (Ampere) }\end{array}$ \\
\hline 1. & & & & & & \\
\hline
\end{tabular}

2. Setelah didapatkan data pada tabel data pengujian, dilakukan pengolahan data berdasarkan persamaan pada bab 2, yaitu perhitungan daya kinetik, daya output generator dan Tips Speed Ratio. Sehingga didapatkan hasil perhitungan dan ditabelkan pada tabel 3.2.

Tabel 3.2 Tabel Data Hasil Perhitungan

\begin{tabular}{|c|c|c|c|c|c|c|}
\hline No. & $\begin{array}{c}\mathrm{V}_{\text {angin }} \\
(\mathrm{m} / \text { detik })\end{array}$ & $\begin{array}{c}\mathrm{V}_{\text {angin depan }} \\
\text { sudu } \\
(\mathrm{m} / \text { detik })\end{array}$ & $\begin{array}{c}\mathrm{P}_{\text {angin }} \\
\text { (Watt) }\end{array}$ & $\begin{array}{c}\mathrm{P}_{\text {gen }} \\
(\text { Watt })\end{array}$ & $\begin{array}{c}\text { Efisiensi } \\
\text { Sistem } \\
\left(\eta_{\text {nistem }}\right)\end{array}$ & $\begin{array}{c}\text { Tips } \\
\text { Speed } \\
\text { Ratio }(\lambda)\end{array}$ \\
\hline 1. & & & & & & \\
\hline
\end{tabular}

3. Setelah dimasukkan ke dalam tabel data perhitungan, kemudian membuat grafik karakteristik hubungan antara efisiensi sistem ( $\eta$ sistem) dengan Tips Speed Ratio (TSR) seperti pada gambar 3.3.

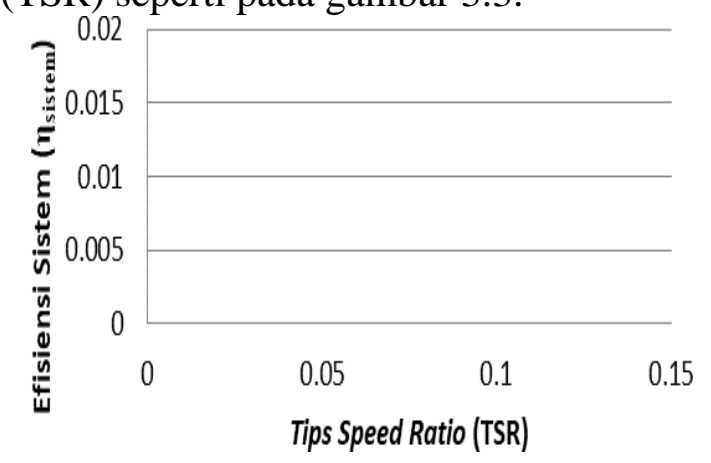

Gambar 3.3 Grafik Karakterisik Hubungan antara Efisiensi Sistem dengan Tips Speed Ratio.

4. Melakukan analisis pada grafik untuk mengetahui efisiensi sistem terbaik ( $\eta$ sistem) pada setiap kecepatan angin.

5. Berdasarkan karakteristik kinerja Efisiensi Sistem tersebut terhadap TSR, puncak Efisiensi di bandingkan untuk 
mendapatkan nilai Efisiensi Sistem (ns) terbaik.

\section{HASIL DAN PEMBAHASAN \\ 4.1 Data Hasil Pengujian}

Setelah melakukan pengujian, contoh data parameter yang terukur disajikan pada Tabel 4.1, data yang ditampilkan pengujian pada posisi tiga sudu tunggal dengan kecepatan $7 \mathrm{~m} /$ detik.

Tabel 4.1 Pengujian Turbin Angin Darrieus Tiga Sudu Tunggal dengan Profil NACA 0018 pada kecepatan angin 7 $\mathrm{m} /$ detik

\begin{tabular}{|c|c|c|c|c|c|c|}
\hline No & $\begin{array}{c}\mathrm{V}_{\text {angin }} \\
(\mathrm{m} / \text { detik })\end{array}$ & $\begin{array}{c}\mathrm{V}_{\text {angin depan sudu }} \\
(\mathrm{m} / \text { detik })\end{array}$ & $\begin{array}{c}\text { Beban } \\
(\text { Watt })\end{array}$ & $\mathrm{n}(\mathrm{rpm})$ & $\begin{array}{c}\mathrm{V}_{\mathrm{DC}} \\
(\text { Volt })\end{array}$ & $\begin{array}{c}\mathrm{I}_{\mathrm{DC}} \\
\text { (Ampere) }\end{array}$ \\
\hline 1 & 7 & 6.8 & 0 & 30.9 & 1 & 0 \\
\hline 2 & 7 & 6.8 & 5 & 22 & 0.12 & 0.01 \\
\hline 3 & 7 & 6.8 & 10 & 15.4 & 0.07 & 0.015 \\
\hline
\end{tabular}

\subsection{Pengolahan Data}

Pada langkah pengolahan data ini diambil sampel pada tabel 4.1 hasil pengujian turbin angin darrieus tiga sudu tunggal dengan profil NACA 0018 pada kecepatan angin $7 \mathrm{~m} /$ detik pada beban lampu 5 Watt. Contoh perhitungan dapat dihitung seperti di bawah ini :

- Kecepatan rata-rata angin lepas $=7$ $\mathrm{m} /$ detik

- Kecepatan angin didepan sudu $=6,8$ $\mathrm{m} /$ detik

- $\quad$ Tegangan keluaran $(\mathrm{VDC})=0,12$ volt

- Arus (IDC) $=0,01$ ampere

- Massa jenis udara = 1,2 kg/m3

- Kecepatan putaran rotor $=22 \mathrm{rpm}$

- Drotor $=0,5 \mathrm{~m}$

- $\quad$ Panjang bilah sudu $=0,7 \mathrm{~m}$

Besarnya daya angin, daya generator, koefisien daya dan Tip Speed Ratio dapat dihitung seperti di bawah ini :

\section{Luas sapuan angin}

$\mathrm{A}=$ Drotor $\mathrm{x}$ Panjang bilah sudu

$=0,5 \mathrm{~m} \mathrm{x} 0,7 \mathrm{~m}$

$=0,35 \mathrm{~m}^{2}$

\section{Daya angin (Pangin) \\ Pangin $=\rho \cdot \mathrm{A} \cdot v^{3}$ \\ $=1,22 \cdot 0,35 .(6,83)$ \\ $=1,452 \mathrm{Watt}$}

\section{Daya generator (Pgen)}

Pgen $=$ VDC. IDC

$=0,12$. 0,01

$=0,0012 \mathrm{Watt}$

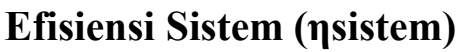

$$
\begin{array}{r}
\eta \text { sistem }=\frac{\text { Poutput }}{\text { Pinput }}=\frac{\text { Pgenerator }}{\text { Pangin }} \\
=\frac{0,0012}{1,428}=0,00083
\end{array}
$$

Tip Speed Ratio $(\lambda)$

$$
\begin{aligned}
\lambda=\frac{\mathrm{u}}{\mathrm{v}}=\frac{(\pi \cdot D \cdot n) / 60}{\mathrm{v}} \\
=\frac{(3,14 \cdot 0,15 \cdot 22) / 60}{7} \\
=0,082
\end{aligned}
$$

\subsection{Data Hasil Perhitungan}

Data hasil perhitungan pengujian turbin angin Darrieus tiga sudu tunggal dengan profil NACA 0018 dan tiga sudu rangkap tiga dengan variasi tiga posisi sudu yang berbeda dengan profil NACA 0006 dengan kecepatan angin $7 \mathrm{~m} /$ detik, 8 $\mathrm{m} /$ detik, $9 \mathrm{~m} /$ detik, $10 \mathrm{~m} /$ detik, $11 \mathrm{~m} /$ detik, dan $12 \mathrm{~m} /$ detik diolah menjadi grafik hubungan antara efisiensi sistem ( $\eta$ sistem) dengan tip speed ratio (TSR). Gambar grafik hasil perhitungan dapat dilihat pada gambar 4.2 sampai gambar 4.7.

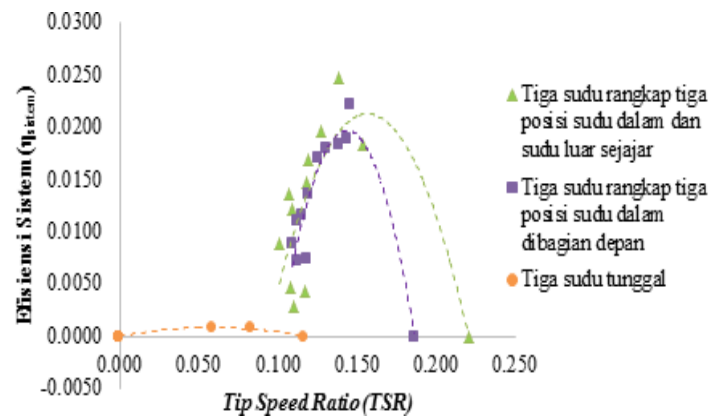

Gambar 4.2 Grafik Karakteristik Hubungan Antara Efisiensi Sistem ( $\left.\eta_{\text {sistem }}\right)$ Terhadap Tip Speed Ratio (TSR) Pada Kecepatan Angin 7 m/detik. 


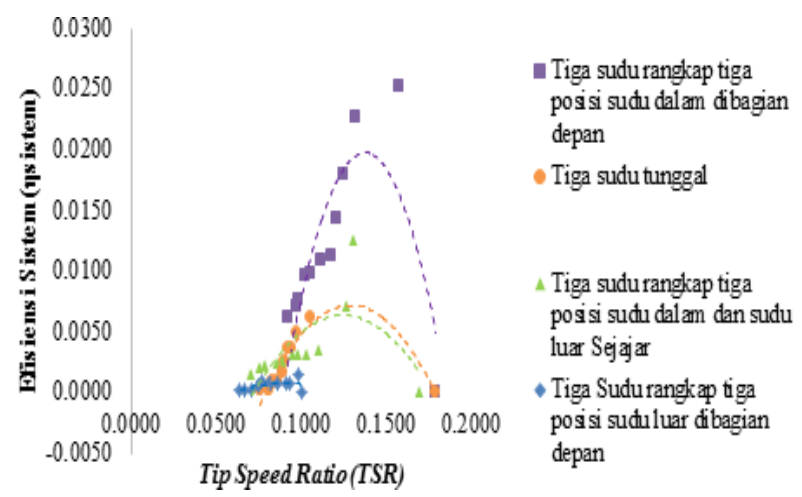

Gambar 4.3 Grafik Karakteristik

Hubungan Antara Efisiensi Sistem $\left(\eta_{\text {sistem }}\right)$

Terhadap Tip Speed Ratio (TSR) Pada

Kecepatan Angin 8 m/detik.

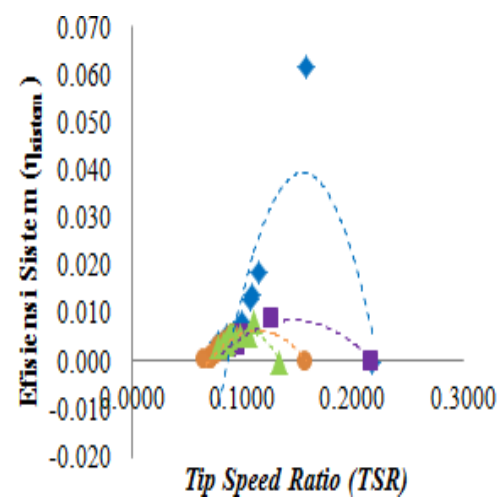

- Tiga sudu rangkap tiga posisi sudu luar dibagian depan

Tiga sudu rangkap tiga posisi sudu dalam dibagian depan

- Tiga sudu tunggal

Gambar 4.4 Grafik Karakteristik

Hubungan Antara Efisiensi Sistem ( $\left.\eta_{\text {sistem }}\right)$ Terhadap Tip Speed Ratio (TSR)

Pada Kecepatan Angin 9 m/detik.

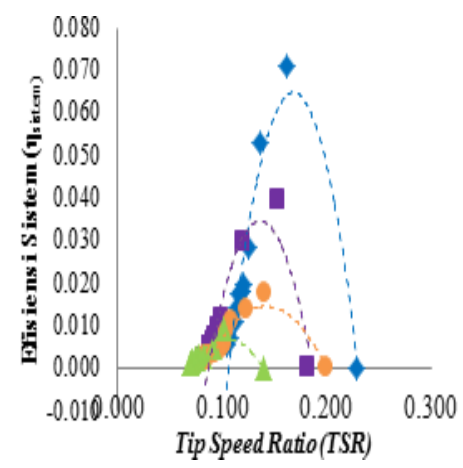

- Tiga sudurangkap tiga posisi suduluar dibagian depan - Iipagan sudu rangkap tiga posisi sudu dal am dibagan depan

$\triangle$ Tiga sudu rangkap tiga posisi sudu dal am dan sudu luar sejajar

Gambar 4.5 Grafik Karakteristik Hubungan Antara Efisiensi Sistem $\left(\eta_{\text {sistem }}\right)$ Terhadap Tip Speed Ratio (TSR) Pada Kecepatan Angin 10 m/detik.

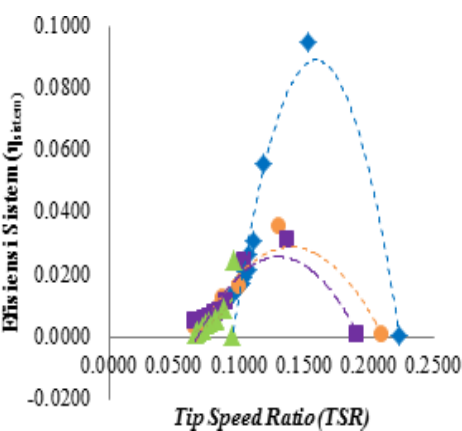

- Tiga sudu rangkap tiga posisi suduluar dibagian depan

- Tiga sudu tunggal

- Tiga sudu rangkap tiga posisi sudu dal am dibagian depan

$\triangle$ Tiga sudu rangkap tiga posisi sudu dal am dan sudu luar sejajar

Gambar 4.6 Grafik Karakteristik Hubungan Antara Efisiensi Sistem ( $\left.\eta_{\text {sistem }}\right)$ Terhadap Tip Speed Ratio (TSR) Pada Kecepatan Angin 11m/detik.

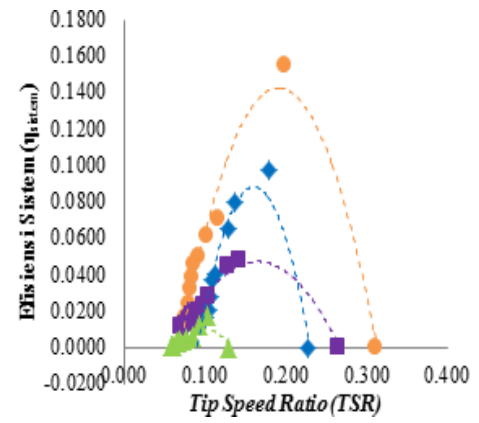

$$
\begin{aligned}
& \text { - Tiga sudu tunggal } \\
& \text { - Tiga sudu rangkap tiga } \\
& \text { posisi suduluar dibagian } \\
& \text { depan } \\
& \text { Tiga sudu rangkap tiga } \\
& \text { posisi sudu dal am dibagian } \\
& \text { depan } \\
& \text { Tiga sudu rangkap tiga } \\
& \text { posisi sudu dal am dan sudu } \\
& \text { luar sejajar }
\end{aligned}
$$

Gambar 4.7 Grafik Karakteristik

Hubungan Antara Efisiensi Sistem $\left(\eta_{\text {sistem }}\right)$ Terhadap Tip Speed Ratio (TSR)

Pada Kecepatan Angin 12m/detik.

\subsection{Pembahasan}

Pengujian dan pengolahan data bertujuan untuk mengetahui karakteristik dari turbin angin Darrieus dengan variasi tiga sudu tunggal dengan profil $N A C A$ 0018 dan tiga sudu rangkap tiga dengan tiga posisi sudu yang berbeda dengan profil NACA 0006. Nilai efisiensi sistem $\left(\eta_{\text {sistem }}\right)$ dipengaruhi oleh daya input yang didapat dari daya angin dan daya keluaran yang berupa daya listrik. Daya angin $\left(\mathrm{P}_{\text {angin }}\right)$ memiliki nilai yang konstan pada kecepatan angin yang diuji yaitu $7 \mathrm{~m} /$ detik, $8 \mathrm{~m} /$ detik, 9m/detik, 10 $\mathrm{m} /$ detik, $11 \mathrm{~m} /$ detik, dan $12 \mathrm{~m} /$ detik. Daya generator $\left(\mathrm{P}_{\text {gen }}\right)$ dipengaruhi oleh tegangan dan arus. Tegangan berbanding lurus dengan putaran $(\mathrm{V} \approx \mathrm{n})$ dan arus berbanding lurus dengan beban. Semakin besar putaran maka tegangan keluaran generator juga semakin besar dan semakin besar beban yang ditambahkan ke dalam sistem turbin Darrieus maka 
semakin besar pula arus yang dihasilkan. Namun pada setiap kenaikan beban putaran akan turun sehingga akan mengakibatkan tegangan keluaran generator juga turun, namun arus akan semakin besar. Dari pengujian turbin angin Darrieus, maka dapat dilihat kurva lengkung terjadi akibat adanya titik saturasi pada generator yang menyebabkan saat kondisi kerja output generator mencapai puncak (maksimal) akan mengalami penurunan. Hal tersebut merupakan karakteristik dari generator pada turbin angin Darrieus.

Berdasarkan data hasil perhitungan efisiensi sistem $\left(\eta_{\text {sistem }}\right)$ dan tip speed ratio (TSR) turbin angin Darrieus yang ditunjukan dalam grafik dapat diketahui bahwa turbin dengan tiga sudu rangkap tiga posisi sudu luar dibagian depan memiliki nilai $\eta_{\text {sistem }}$ dan TSR yang lebih tinggi dibandingkan tiga sudu tunggal, tiga sudu rangkap tiga posisi sudu dalam didepan, dan tiga sudu rangkap tiga posisi sudu dalam dan luar sejajar yaitu pada kecepatan angin $9 \mathrm{~m} /$ detik, 10 $\mathrm{m} /$ detik, dan $11 \mathrm{~m} /$ detik.Masingmasing $\eta_{\text {sistem }}$ yaitusebesar0,0085;0,039;0, 0309. Dan TSR masing-masing sebesar0,1277;0,154; 0,138. Pada kecepatan angin $7 \mathrm{~m} /$ detik turbin angin Darrieus tiga sudu rangkap tiga posisi sejajar memiliki nilai $\eta_{\text {sistem }}$ dan TSR yanglebihtinggi dibandingkan tiga sudu tunggal, tiga sudu rangkap tiga posisi sudu luar didepan, dan tiga sudu rangkap tiga posisi sudu luar dibelakang yang memiliki $\eta_{\text {sistem }}$ dan TSR masing-masing sebesar 0,0183 dan 0,153 . Sementara itu pada kecepatan angin $8 \mathrm{~m} /$ detik turbin angin Darrieus tiga sudu rangkap tiga posisi sudu dalam didepan memiliki nilai $\eta_{\text {sistem dan TSR yang lebih tinggi }}$ dibandingkan tiga sudu tunggal, tiga sudu rangkap tiga posisi sudu luar didepan, dan tiga sudu rangkap tiga posisi sudu luar dan sudu dalam sejajar yang memiliki $\eta_{\text {sistem }}$ dan TSR masingmasing sebesar 0,0252 dan 0,1581. Pada kecepatan angin $12 \mathrm{~m} /$ detik turbin angin
Darrieus tiga sudu tunggal memiliki nilai $\eta_{\text {sistem }}$ dan TSR yang lebih tinggi dibandingkan 3 rangkap tiga posisi sejajar, tiga sudu rangkap tiga posisi sudu luar didepan, dan tiga sudu rangkap tiga posisi sudu luar dibelakang yang memiliki $\eta_{\text {sistem }}$ dan TSR masing-masing sebesar 0,1548 dan0,2.

Posisi tiga sudu tunggal kecepatan angin $7 \mathrm{~m} /$ detik hingga $12 \mathrm{~m} /$ detik nilai $\eta_{\text {sistem }}$ yaitu masing-masing sebesar 0,$00083 ; \quad 0,0061 ; \quad 0,0055 ; \quad 0,0174$; 0,$035 ; 0,1548$ dan TSR 0,$082 ; 0,1050$; 0,$093 ; 0,141 ; 0,1316 ; 0,2$.Nilai $\eta_{\text {sistem }}$ dari tiga sudu rangkap tiga posisi sudu luar didepan dengan kecepatan angin 7 $\mathrm{m} /$ detik hingga $12 \mathrm{~m} /$ detik yaitu 0 ; 0,0016; 0,062; 0,071;0,0949; 0,0977 dan TSR masing-masing yaitu0;0,0975; 0,$1571 ; 0,161 ; 0,1535 ; 0,18$. Pada saat tigasudu rangkap tiga posisi sudu dalam didepan nilai $\eta_{\text {sistemyaitu0,0221;0,0252;0,0085;0,039;0 }}$ ,0309;0,0476 dan TSR masingmasiingyaitu 0,$145 ; 0,1581 ; 0,1277 ; 0,1545 ; 0,138 ; 0,141$ .Nilai $\eta_{\text {sistem }}$ untuk tiga sudu rangkap tiga posisi sejajar masing- masing yaitu 0,$0183 ; 0,0125 ; 0,0081 ; 0,0095 ; 0,0245$; 0,0173 dan TSR masing-masing yaitu0,153; 0,$1306 ; \quad 0,1101 ; \quad 0,101$; 0,096; 0,103.

Kecepatan angin $7 \mathrm{~m} /$ detik turbin angin Darrieus dengan NACA 0006 tiga sudu rangkap tiga posisi sudu dalam dan sudu luar sejajar memiliki efisiensi sistem tertinggi daripada posisi yang lainnya, sehingga pada kecepatan $7 \mathrm{~m} /$ detik lebih cocok menggunakan turbin angin Darrieus dengan NACA 0006 tiga sudu rangkap tiga posisi sudu dalam dan sudu luar sejajar. Kecepatan angin $8 \mathrm{~m} /$ detik turbin angin Darrieus dengan NACA 0006 tiga sudu rangkap tiga posisi sudu dalam dibagian depan memliki efisiensi sistem tertinggi daripada posisi yang lainnya, sehingga pada kecepatan $8 \mathrm{~m} /$ detik lebih cocok menggunakan turbin angin Darrieus dengan NACA 0006 tiga sudu rangkap tiga posisi sudu sudu dalam dibagian depan. 
Kecepatan angin $9 \mathrm{~m} /$ detik hingga $11 \mathrm{~m} /$ detik turbin angin Darrieus dengan NACA 0006 tiga sudu rangkap tiga posisi sudu luar dibagian depan memliki efisiensi sistem tertinggi daripada posisi yang lainnya, sehingga pada kecepatan 9 $\mathrm{m} /$ detik hinggan $11 \mathrm{~m} /$ detik lebih cocok menggunakan turbin angin Darrieus dengan NACA 0006 tiga sudu rangkap tiga posisi sudu sudu luar dibagian depan. Turbin angin Darrieusdengan

NACA 0018 tiga sudu tunggal pada kecepatan angin $12 \mathrm{~m} /$ detik memiliki efisiensi sistem tertinggi daripada posisi yang lainnya, sehingga pada kecepatan 12 $\mathrm{m} /$ detik lebih cocok menggunakan turbin angin Darrieus dengan NACA 0018 tiga sudutunggal.

\section{PENUTUP}

\subsection{Kesimpulan}

Hasil rancang bangun turbin angin tipe Darrieus tiga sudu rangkap tiga dengan profil NACA 0006 berbahan plat alumunium dapat disimpulkan sebagai berikut:

1. Turbin angin Darrieus dengan NACA 0018 dibuat dengan bahan plat alumunium dengan ketebalan sudu $18 \%$ dari line chord. Turbin angin Darrieus dengan NACA 0006 dibuat dengan bahan plat alumunium dengan ketebalan sudu $6 \%$ dari line chord dengan variasi posisi sudu yaitu tiga sudu rangkap tiga posisi sudu dalam dibagian depan, tiga sudu rangkap tiga posisi sudu luar dibagian depan, dan tiga sudu rangkap tiga posisi sudu dalam dan sudu luarsejajar.

2. Hasil uji turbin angin Darrieus dengan profil sudu NACA 0018 tiga sudu tunggal menghasilkan nilai efisiensi sistem $\left(\eta_{\text {sistem }}\right)$ terbesar pada kecepatan angin $12 \mathrm{~m} /$ detik yaitu sebesar 0,1548 . Pada turbin angin Darrieus dengan profil sudu NACA 0006 tiga sudu rangkap tiga posisi sudu luar didepan menghasilkan efisiensi sistem $\left(\eta_{\text {sistem }}\right)$ terbesar pada kecepatan angin 7 $\mathrm{m} /$ detik hingga $12 \mathrm{~m} /$ detik yaitu sebesar 0,0977 . Pada saat tiga sudu rangkap tiga posisi sudu dalam didepan nilai $\eta_{\text {sistem }}$ terbesar pada kecepatan $12 \mathrm{~m} /$ detik yaitu 0,0476 . Nilai $\eta_{\text {sistem }}$ terbesar untuk posisi tiga sudu rangkap tiga posisi sejajar pada kecepatan $11 \mathrm{~m} /$ detik yaitu0,0245.

3. Kecepatan angin $7 \mathrm{~m} /$ detik efisiensi tertinggi didapat pada tiga sudu rangkap tiga posisi sudu dalam dan sudu luar sejajar. Kecepatan angin 8 $\mathrm{m} /$ detik efisiensi tertinggi didapat pada tiga sudu rangkap tiga sudu dalam dibagian depan. Kecepatan angin $9 \mathrm{~m} /$ detik, $10 \mathrm{~m} /$ detik dan 11 $\mathrm{m} /$ detik efisiensi tertinggi didapat tiga sudu rangkap tiga posisi sudu luar dibagian depan. Kecepatan angin 12 $\mathrm{m} /$ detik efisiensi sistem tertinggi didapat pada tiga sudu tunggal $N A C A$ 0018.

\subsection{Saran}

Pengerjaan dan penyelesaian tugas akhir ini tentu tidak lepas dari berbagai macam kekurangan dan kelemahan. Untuk memperbaiki kekurangan tersebut maka saran yang diberikan sebagai berikut

1. Menambah tail pada setiap sudu untuk meminimalisir hambatan pada setiap sudu sehingga turbin dapat berputar denganmaksimal.

2. Tempat uji turbin angin dilakukan di tempat yang dapat meminimalkan rugi-rugi yang dapat membuat kecepatan angin tidak stabilsepertidibuat lorong khusus untuk pengujian turbin angin.

3. Penggunaan simulasi dengan software komputer saat melakukan uji kinerja turbin angin agar dapat digunakan sebagai pembanding dengan hasil uji kinerja turbin angin secara eksperimental. Serta meminimalisir resiko yang ditimbulkan saat pembuatan blade dan pengujian turbin anginberlangsung 


\section{DAFTAR PUSTAKA}

- Cross, Mike. 1987. Tenaga Angin. Terjemahan oleh M. Tazir. Jakarta: Pradnya Paramita.

- Hau, Erich. 2005. Wind Turbines Fundamentals, Technologies, Application, Economics, 2nd Edition, terjemahan Horts von Renourd, Spinger. Germany.

- Hofman H dan Harun. 1987. Energi Angin. Jakarta : Binacipta.

- Kadir, Abdul. 2005. Energi Sumberdaya, Inovasi, Tenaga Listrik Dan Potensi Ekonomi. Jakarta: Universitas Indonesia (UIPers).

- Pudjanarso, Astu dan Djati Nursahud. 2015. Mesin Konversi Energi Edisi 3. Yogyakarta: C.V Andi Offset.

- Raharjo, Panggih. "NACA Airfoil". 5 April 2018.

http://indonesia.windprospecting.co $\mathrm{m} /$.

- Yunus, Muhammad (dkk). 2017. Pengembangan Turbin Angin Tipe Darrieus Tiga Sudu Ganda dengan Profil NACA 0016. Laporan Tugas Akhir Teknik Konversi Eenrgi Politeknik Negeri Semarang. Semarang

- - -------------. “Angin Darat dan Angin Laut”. 18 Juni 2018. https://id.wikipedia.org/wiki/Angin _darat_dan_angin_laut.

- - ----------------. "Berkas:

Wind rose plot. jpg". 4 Maret 2018. https://id.wikipedia.org/wiki/Berkas :Wind_rose_plot.jpg

- --------------------. "NACA 0006 - NACA 0006 Airfoil”. 18 Agustus 2018. http://airfoiltools.com/airfoil/details ?airfoil=naca0006-il.

- - -----------------. "Pengertian

Angin, Sifat dan Jenis-jenis Angin". 4 Maret 2018. http://www.artikelsiana.com/2015/0 4/angin-Pengertian-angin-jenismacam-macam-angin.html.
Energy Resource of Indonesia". 4 Maret 2018. http://indonesia.windprospecting.c om/. 